\title{
GENDER DIFFERENCES IN LANGUAGE LEARNING STYLE AND LANGUAGE LEARNING STRATEGIES
}

\author{
Chayata Viriya \& Sutthirak Sapsirin \\ Chulalongkorn University \\ chayataviriya@gmail.com \\ sapsirin@yahoo.com
}

\begin{abstract}
This paper seeks to investigate the gender differences in language learning style and language learning strategies. The study used the perceptual learning-style preference questionnaire (PLSPQ) to investigate the learning style preferences and the Strategy Inventory for Language Learning (SILL) version 7.0 designed by Oxford (1990) to find the learning strategy preferences of first year University students at the faculty of Information and Communication Technology (ICT) in Thailand. These were administered to 150 learners. The results indicate that gender does have effects on language learning style but there is no effect on language learning strategies. The implication of the results for language teachers and learners are also presented.
\end{abstract}

Keywords: language learning style, language learning strategies, gender

\section{PERBEDAAN-PERBEDAAN GENDER DALAM GAYA BELAJAR BAHASA DAN STRATEGI-STRATEGI BELAJAR BAHASA}

\begin{abstract}
Abstrak: Makalah ini berusaha untuk menyelidiki perbedaan-perbedaan gender dalam gaya belajar bahasa dan strategi-strategi belajar bahasa. Kajian ini menggunakan angket pilihan gaya belajar perseptual (the perceptual learning-style preference questionnaire (PLSPQ)) untuk menyelidiki pilihan-pilihan gaya belajar dan Inventaris Strategi untuk Belajar Bahasa (the Strategy Inventory for Language Learning (SILL)) versi 7.0 yang dirancang oleh Oxford (1990) untuk menemukan pilihan-pilihan strategi belajar mahasiswa Universitas di Fakultas Teknologi Komunikasi dan Informasi. Angket-angket tersebut diberikan pada 150 pembelajar. Hasilnya menunjukkan bahwa gender memang memiliki pengaruh terhadap gaya belajar bahasa, tapi tidak berpengaruh pada strategi-strategi belajar bahasa. Implikasi dari hasil ini bagi para guru dan pembelajar bahasa juga dihadirkan.
\end{abstract}

Kata kunci: Gaya belajar bahasa, strategi-strategi belajar bahasa, gender

Learning style and learning strategies have been the topic of discussions for a long time. Many researchers have been trying to find possible factors that affect learning style and strategies. One of the factors that caught the attention is gender differences. Males and females learn differently from each other (Ebel, 1999; Cavanaugh, 2002, as cited in Tatarinceva, 2009). Males tend to be more visual, more peers motivated and learn less by listening than females. In contrast, females tend to be auditory and learn well when it is quiet (Marcus, 1999; Pizzo, 2000, as cited in Tatarinceva, 2009). Tannen (1992) suggests that male students prefer doing learning tasks which involve the talk in public settings more because they feel compelled to establish or maintain their position in the group. On the other hand, female students prefer talking more in private settings because they see conversation as an important way of maintaining relationships. Furthermore, 
females are better than males at language learning tasks relating to remembering verbal information, faces, names, and object locations. As for males, they do better with the travel directions tasks (Colley, 2001; Ong, 1999; Larrabee \& Crook, 1993 as cited in Tatarinceva, 2009). Also, Kraft and Nichel (1995) proved that females were better at verbal fluency, vocabulary and quality of speech, but male students were better at writing. Still, despite many studies, inconclusive evidence on the influence of gender differences has been found (see Oxford and Nyikos, 1989 or Taguchi, 2002).

As for learning strategies, various learners' factors have been identified as factors related to language learning strategies, including language being learned, level of language learning, proficiency, degree of metacognitive awareness, gender, affective variables such as attitudes, motivation, and language learning goals, specific personality traits, overall personality type, learning style, career orientation or field of specialization, national origin, aptitude, language teaching methods, task requirements, and type of strategy training (Oxford \& Nyikos, 1989). In terms of gender and language learning strategies, Kamarul et al. (2009) show that females report using language learning strategies more often than males and there are significant differences between genders in the use of affective and metaphysic strategies. Females tend to use them more often than males. According to the aforementioned issue, it can be seen that gender is one of the factors that can influence both language learning styles and strategies. Therefore, the present study aims to investigate the gender differences in language learning styles and language strategies that Thai learners prefer. The objectives of the present study are to identify language learning styles and strategies used by first year university students in Thailand, and to examine gender differences in those two variables.

\section{Language Learning Styles}

According to Reid (1998), language learning style is an internally based characteristics, often not perceived or consciously used by learners, for the intake and comprehension of new information' (p. ix). Reid (1998) reiterates that there are six major learning style preferences, covering visual, auditory, kinesthetic, tactile, group and individual. Firstly, students who prefer the visual learning style 'learn well from seeing words in books, on the chalkboard, and in workbooks. Students can remember and understand information and instructions better if their teachers read them. Students will not need a lot of oral explanation and they can learn alone with a book' (p. 165). Secondly, students who prefer the auditory learning style 'learn well from hearing words spoken and from oral explanation. Students can remember information by reading aloud or by moving their lips as they read; especially, when they are learning new materials. They will learn well from audiotapes, lectures, and class discussion' (p. 165). Thirdly, students who prefer the kinesthetic learning style learn best by 'experience or by being physically involved in classroom experiences. Students can remember information well when they actively participate in activities, role-play, field trips and etc' (p. 166). Fourthly, students who prefer the tactile learning style learn best 'when they have an opportunity to do 'handson' experiences with materials. That is, working on experiments in a laboratory, handling and building models, and touching and working with materials provide students with the most successful learning situations' (p. 166). Fifthly, students who prefer the group learning style learn best when 'they are studying in a group or at least with another student. Students value group interaction and class work with other students and can remember information better when they work with two or three classmates. The stimulation and motivation students gain from group work 
or learn or work with others help them learn and understand new information better' ( $p$. 166). Finally, students who prefer the individual learning style learn best when 'they work alone. Students can think better when they study alone, and they remember information learned by themselves. They understand materials best when they learn them alone, and they make better progress in learning when they work by themselves' (p. 166).

There are some studies in the past about language learning styles and students' learning. According to Reid (1987), one of the studies presents the results of a questionnaire that was used to ask 1,388 students to identify their perceptual learning style preferences. Statistical analyses of the questionnaires indicated that NSS (native speakers of English) learning style preferences often differ significantly from those of NNSS (non-native speakers of English). In other words, ESL students from different language backgrounds sometimes differ from one another in their learning style preferences. Moreover, other variables such as gender, length of time abroad, field of study, level of education, TOEFL score, and age are related to differences in learning styles.

In Thailand, Wasanasomsithi (2003) has studied learning style of Thai learners who learn English as a foreign language. The results show that the learners prefer group learning and auditory style than individual or visual style, which contradicts Reid's study (1987).

As for learning style and gender, Mulalic et al. (2009) examine the learning styles of students, and the differences in their learning styles according to their gender and ethnicity. There was a significant difference in learning style between male and female students regarding auditory and kinesthetic learning styles. The mean score for the male was higher in both cases, which means that male students favored kinesthetic and auditory leaning when compared with the female counterparts. This is in agreement with Dunn and Griggs' (1993, as cited in Mulalic et al., 2009) study in which they found significant differences in learning styles of Mexican and Anglo-American students. Mexican American males had strongest preferences for tactile learning but female participants show a different result.

Moreover, according to Wehrwein et al. (2007), students are believed to have individual learning style preferences. They assessed students' preferences by using the VARK questionnaires, which was created by Fleming (Visual, Auditory, Read-write and Kinesthetic) to undergraduate physiology majors enrolled in a capstone physiology laboratory at Michigan State University. The result is that male and female students have significantly different learning styles. A majority of male students preferred multimodal instruction, specifically, four modes (VARK), whereas a majority of female students preferred single-mode instruction with a preference toward the kinesthetic style. Thus, it is the responsibility of the instructors to address this diversity of learning styles and develop appropriate learning approach.

In addition, Maubacha and Morgan (2001) examine the truth of the relationship between gender and language learning styles. They examine a small sample of 57 girls and 15 boys A level French and German. They found four main gender related characteristics: a male willingness to take risks, a male willingness to speak spontaneously in a foreign language, a greater male self confidence about asking questions of the teacher to aid their own understanding and the female students' interest in reading and presenting well-organized written work.

\section{Language Learning Strategies}

There are many definitions and explanations for the concept of learning strategies. Rubin (1981, as cited in Purpura, 1999), identified 
six strategy types: clarification or verification, monitoring, memorization, guessing or inductive inferencing, deductive reasoning and independent practice. O'Malley and Chamot (1990, as cited in Purpura, 1999) proposed the framework of strategies, which distinguishes three major strategy types. They are metacognitive strategies, cognitive strategies and socio-affective strategies. Each strategy type is further divided into a number of individual strategies. For example, the metacognitive strategies include advance organizers, directed attention, selective attention, self-management, advance preparation, self-monitoring, delayed production and self-evaluation.

Lastly, Oxford (1990) proposed two major classes of learning strategies, which are direct and indirect. These two classes are subdivided into a total of six groups, which are memory, cognitive, compensation strategies. These are all under the direct class. The metacognitive, affective, and social are under the indirect class.

Direct strategies or memory strategies are the language learning strategies that directly involve the target language (Oxford, 1990, p. 37,). The first type of direct strategies is memory strategies, which consist of creating mental linkages, applying images and sounds, reviewing well, and employing actions (Oxford, 1990).

The second types of direct strategies is cognitive strategies, such as summarizing or reasoning deductively, enabling learners to understand and produce new language by many different means (Oxford, 1990, p. 37,). Cognitive strategies are essential in learning a new language. It consists of four sets, practicing, receiving and sending messages, analyzing and reasoning and creating structure for input and output (Oxford, 1990).

The third type of direct strategies is compensation strategies, like guessing or using synonyms, which allow learners to use the language despite their often large gaps in knowledge (Oxford, 1990, p. 37). Compensation allows learners to produce spoken or written expression in the new language without complete knowledge like to guess the meaning of a word, gestures or coining words. Many of compensation strategies are used to compensate the lack of appropriate vocabulary or grammatical knowledge. This way will help learners to understand more about target language and help learners to keep on using the target language by practicing it. Sometimes it helps learners to become more fluent in what they already know and may lead them to gain new information about what is appropriate or permissible in the target language. It consists of two strategies in the compensation strategies, which are guessing intelligently and overcoming limitations in speaking and writing (Oxford, 1990).

Indirect strategies are 'the strategies that underpin the business of language learning' (Oxford, 1990, p. 135,). It is called indirect because these strategies support and manage language learning without directly involving the target language. They are divided into metacognitive, affective and social strategies (Oxford, 1990). The first type of indirect strategies is metacognitive strategies, which means beyond, beside, or with the cognitive. Therefore, metacognitive strategies are actions which go beyond purely cognitive devices, and which provide a way for learners to coordinate their own learning process (Oxford, 1990, p. 136). It consists of three strategies in this set, which is centering your learning, arranging and planning your learning and evaluating your learning (Oxford, 1990).

The second type of indirect strategies is affective strategies, which refer to emotions, attitudes, motivations, and values (Oxford, 1990 p. 140). This strategy should not be overlooked because positive emotions and attitudes can make language learning far more effective and enjoyable. On the other hand, negative feelings can stunt progress. For 
example, a certain amount of anxiety sometimes helps learners to reach their peak performance levels, but too much anxiety can block language learning. Within this affective strategies, they consist of three sub-strategies that will help students to achieve it, which are lowering your anxiety, encouraging yourself and taking your emotional temperature (Oxford, 1990).

The third type of indirect strategies is social strategies: language is a form of social behavior; it is a communication, and communication occurs between and among people. Learning a language thus involves other people, and appropriate social strategies are very important in this process (Oxford, 1990, p. 144). There are three strategies to achieve this social strategy, asking questions, cooperating with others, and empathizing with others (Oxford, 1990).

Several studies have been conducted on language learning strategies. For example, Wafa (2003) reports on the current English language learning strategies used by Arabicspeaking English-majors enrolled at An-Najah National University in Palestine. The subjects of the study are male and female students still studying for their B.A. degree. The results of this study show that An-Najah English majors use learning strategies with high to medium frequency, and the highest rank $(79.6 \%)$ is for metacognitive strategies while the lowest $(63 \%)$ is for compensation strategies. In general, the results show that gender and proficiency have no significant differences on the use of strategies.

Another gender study on language learning strategies belongs to Kamarul et al. (2009), the findings of the study show that there are important gender differences in the use of language learning strategies. Female students also tend to use overall language learning strategies more often than males, especially with affective and metaphysic strategies (Oxford 1990).

\section{METHOD}

To understand learning styles of individuals is not an easy task. The instrument to examine learning styles is the key. It should be reliable and valid. (Reid, 1998) There are many language learning style preferences survey (Reid, 1984, as cited in Watanasin, 2004). However, among the learning style inventory, the Reid's Perceptual Learning Style Preference Questionnaire (PLSPQ) is the first one designed for English as Second Language (ESL) students at the university level (Reid, 1984) and it matches the present study's purpose.

The PLSPQ is in the form of the five point Likert scale, which is adapted from the original seven point Likert scale format of Gardner's attitude and motivation test ranging from strongly agree to strongly disagree. There are 30 questions with statements for each of the six learning style preferences: visual, auditory, kinesthetic, tactile, group learning, and individual learning. The questions are all random (Reid, 1998).

For language learning strategies, the instrument that is widely used for investigating the language learning strategies is the Strategy Inventory for Language Learning (SILL), constructed by Oxford. It has been used in many parts of the world with learners of many different languages, for example, Chinese, English, French, Thai, Turkish, etc. This study adopts the version 7 SILL, containing 50 items. It is geared to students of English as a second or foreign language and takes about 30 minutes to complete, depending on the skill level of the students. The language is very simplified. The SILL is five-point scale ranging from 'never or almost never' to 'always or almost always'. The average indicates how often the learner tends to use learning strategies. The averages for each part of the SILL indicate which strategy groups the learner tends to use most frequently (Oxford, 1990). 
The reason why Oxford's SILL version 7.0 was used in this study is because SILL is approved as 'the most comprehensive classification of learning strategies to date' and it is also the most often used strategy scale around the world (Ellis, 1994). Moreover, Ellis (1994) states that Oxford's taxonomy is unique in that it made no distinction between strategies that were invoked in both language learning and language use.

Each choice of the questionnaire covers different strategies. There are six choices, remembering more effectively, using your mental processes, compensating for missing knowledge, organizing and evaluating your learning, managing your emotions and learning with others (Oxford, 1990).

The researcher collected the data by herself after the midterm exam on the $3^{\text {rd }}$ of August 2010 at the faculty of Information and Communication Technology (ICT), of a university in Thailand. Before handing out the questionnaires at the end of the class, the researcher explained to students what this research was about, what they had to do and asked for their cooperation.

\section{FINDINGS AND DISCUSSION}

This section presents the results of the study and discusses the findings. The first part deals with the findings about the overall learning style preferences of male and female ICT students. The second part deals with their overall language learning strategies.

Table 1: Number of students for each learning style preference

\begin{tabular}{|c|c|c|c|c|c|c|c|}
\hline \multicolumn{9}{|c|}{ Language learning styles } \\
\hline \multicolumn{3}{|c|}{ Male (70 students) } & \multicolumn{5}{|c|}{ Female (80 students) } \\
\hline & $\begin{array}{l}\text { Maj } \\
\text { or }\end{array}$ & $\begin{array}{l}\text { Min } \\
\text { or }\end{array}$ & $\begin{array}{l}\text { Neg } \\
\text { ligi } \\
\text { ble }\end{array}$ & & Major & $\begin{array}{l}\text { Min } \\
\text { or }\end{array}$ & $\begin{array}{l}\text { Neglig } \\
\text { ible }\end{array}$ \\
\hline Visual & 18 & 46 & 6 & Visual & 31 & 48 & 1 \\
\hline Tactile & 19 & 48 & 3 & Tactile & 31 & 49 & 0 \\
\hline
\end{tabular}

\begin{tabular}{|l|c|c|c|l|c|c|c|}
\hline $\begin{array}{l}\text { Audi- } \\
\text { tory }\end{array}$ & 24 & 24 & 22 & $\begin{array}{l}\text { Audi- } \\
\text { tory }\end{array}$ & 36 & 46 & 0 \\
\hline Group & 35 & 31 & 4 & Group & 47 & 33 & 0 \\
\hline $\begin{array}{l}\text { Kinest } \\
\text { hetic }\end{array}$ & 20 & 44 & 6 & $\begin{array}{l}\text { Kines- } \\
\text { thetic }\end{array}$ & 34 & 46 & 1 \\
\hline $\begin{array}{l}\text { Indivi- } \\
\text { dual }\end{array}$ & 15 & 32 & 23 & $\begin{array}{l}\text { Indivi- } \\
\text { dual }\end{array}$ & 28 & 52 & 18 \\
\hline
\end{tabular}

As for the interpretation of language learning styles, there are three major interpretations, which are major, minor and negligible. Major learning styles score indicate areas where students can function best as a learner. Minor learning style score indicates areas where students can function well as a learner. Negligible learning style score indicates that students may have difficulties with learning in that way.

Table 2 Percentage of students for each learning style preference

\begin{tabular}{|l|c|c|c|l|c|c|c|}
\hline \multicolumn{5}{|c|}{ Manguage learning styles } \\
\hline & $\begin{array}{l}\text { Maj } \\
\text { or }\end{array}$ & $\begin{array}{l}\text { Min } \\
\text { or }\end{array}$ & $\begin{array}{l}\text { Neglig } \\
\text { ible }\end{array}$ & & $\begin{array}{l}\text { Maj } \\
\text { or }\end{array}$ & $\begin{array}{l}\text { Min } \\
\text { or }\end{array}$ & $\begin{array}{l}\text { Neglig } \\
\text { ible }\end{array}$ \\
\hline Visual & 25 & 65 & 8 & Visual & 38 & 60 & 1 \\
\hline Tactile & 27 & 68 & 4 & Tactile & 38 & 61 & 0 \\
\hline $\begin{array}{l}\text { Audito } \\
\text { ry }\end{array}$ & 34 & 34 & 31 & $\begin{array}{l}\text { Audito } \\
\text { ry }\end{array}$ & 45 & 57 & 0 \\
\hline Group & 50 & 44 & 5 & Group & 58 & 41 & 0 \\
\hline $\begin{array}{l}\text { Kinest } \\
\text { hetic }\end{array}$ & 28 & 62 & 8 & $\begin{array}{l}\text { Kinest } \\
\text { hetic }\end{array}$ & 42 & 51 & 1 \\
\hline $\begin{array}{l}\text { Individ } \\
\text { ual }\end{array}$ & 21 & 45 & 32 & $\begin{array}{l}\text { Individ } \\
\text { ual }\end{array}$ & 35 & 65 & 22 \\
\hline
\end{tabular}

Table 1 shows the number of male and female students who chose different types of learning styles based on PLSPQ questionnaires. As the total number of the participants was different $\quad$ (male $=70$, female $=80$ ), to compare their learning styles, percentage of learning style preference was calculated (Table 2).

To clarify what it has already been presented, the mean scores of male and female 
learning styles preferences were calculated. According to Reid (1987), the mean score 17.91 and above is considered major learning style preference; the mean score 15.91 to 17.90 is considered minor learning style preference; and the mean score 15.91 or lower is considered negative learning style preference.

Table 3: Mean scores of male and female learning styles preferences

\begin{tabular}{|c|c|c|c|c|}
\hline & Male & Type & Female & Type \\
\hline Visual & 16.69 & Minor & 17.45 & Minor \\
\hline Tactile & 16.97 & Minor & 17.93 & Major \\
\hline Auditory & 17.49 & Minor & 18.35 & Major \\
\hline Group & 18.22 & Major & 19.26 & Major \\
\hline Kinesthetic & 17.07 & Minor & 18.25 & Major \\
\hline Individual & 14.91 & Negative & 16.43 & Minor \\
\hline
\end{tabular}

Table 3 shows the preferences of learning styles by both males and females. As it can be seen, the visual learning style was chosen as a minor style by both groups (mean $=16.68$ for males and 17.45 for females). The tactile style was chosen as a minor style by males (mean=16.97) and a major style by females (mean=17.93). For the auditory style, it was chosen as a minor style by males $($ mean $=17.49)$ and a major styles by females (mean=18.35). For the group style, it was chosen as a major style by both groups (mean $=18.22$ for males and 19.26 for females). For the kinesthetic style, it was chosen as a minor style by males (mean=17.07) and a major style by females (mean=18.25). Finally, for the individual style, it was chosen as a negative style by males $($ mean=14.91) and a minor style by females $($ mean $=16.43)$.

The results show that for the visual style, males and females can learn well with the eyes (seeing). For the tactile, females can learn best and males can learn well with hands-on activities. For the auditory, females can learn best and males can learn well with the ears (listening). For the group style, both females and males can learn best when they are working with their friends but females tend to learn with this style better than males. For the kinesthetic, females can learn best and males can learn well with experiential learning. Lastly, for the individual style, females can learn well and males have some difficulties learning or working alone.

As for the result of language learning strategies, there are five interpretations for each strategy, which are always or almost always used, usually used, sometimes used, generally not used and never or almost never used. The abbreviations of the interpretations and strategies are as follows:

H1: high, always or almost always used; H2: high, usually used; M: medium, sometimes used; L1: low, generally not used; L2: low, never or almost never used; $\mathbf{A}$ : remembering more effectively; $\mathbf{B}$ : using all your mental processes; $\mathbf{C}$ : compensating for missing knowledge; D: organizing and evaluating your learning; E: managing your emotions; $\mathbf{F}$ : Learning with other

\begin{tabular}{|c|c|c|c|l|}
\hline & Male & Used & Female & Used \\
\hline A & 2.95 & Sometimes & 3.05 & Sometimes \\
\hline B & 3.13 & Sometimes & 3.15 & Sometimes \\
\hline C & 3.08 & Sometimes & 3.18 & Sometimes \\
\hline D & 3.36 & Sometimes & 3.28 & Sometimes \\
\hline E & 3.10 & Sometimes & 3.23 & Sometimes \\
\hline F & 2.97 & Sometimes & 3.26 & Sometimes \\
\hline
\end{tabular}

The above table shows the use of learning strategies by both males and females. As it can be seen, all of the strategies are sometime used. (mean for male $=2.95,3.13,3.08,3.36$, 3.10 , and 2.97, respectively and mean for female $=3.05,3.15,3.18,3.28,3.23$, and 3.26 respectively)

For remembering more effectively, females used it more than males. For using all 
your mental processes, females and males equally used it. For compensating for missing knowledge, females used it more than males. For organizing and evaluating your learning, males used it more than females. For managing your emotions, females used it more than males. Finally, for learning with others, females used it more than males.

From all of these results, it shows that there is a gender difference in language learning styles. For tactile, males prefer the minor learning style while females prefer the major learning styles as well as auditory and kinesthetic. For individual, males prefer the negative learning style while females prefer the minor learning style. For visual, both males and females prefer the minor learning style. Finally for group, both males and females prefer the major learning style. However, for language learning strategies, there is no difference in strategies. Both groups sometimes used all the strategies.

This study aims to study gender differences in language learning style and strategies. The result of the study shows that both males and females were different in terms of styles but were not different in terms of strategies.

The results of the study are different from Reid (1987) in two aspects. Firstly, according to Reid's study, Thai learners who learn English see themselves as having the individual learning style preference. However, this study shows that they prefer the group learning style rather than the individual learning style. Secondly, according to Reid's study, Thai learners who learn English see themselves as haing the visual learner. However, this study shows that they prefer the auditory learning. Moreover, this study shares the same results with Wasanasomsithi's study (2003) who conducted a research on learning styles of English as second language learners of Thai students.

The present study also found that they prefer the group and the auditory as their major preferences. Visual, tactile and kinesthetic are of the minor preferences and the individual learning are of the negative preference.

The researcher thinks that the reason why both males and females preferred the group style and why individual style was negative is because our Thai culture or Asian culture seems to value Collectivism (Kim et al., 1984, as cited in Kim, 2004). In the collectivism culture, students seem to hesitate to answer the questions, cannot freely express their opinions, remain silent during class, etc. Collectivism promotes adherence to norms, respect for elders, group consensus, fostering interdependence and group success and etc.

For this study, the researcher believes that Thailand's educational system is categorized in this collectivism category. This is in contrast with the Western individualism (Kim et al., 1984, as cited in Kim, 2004). Individualism mainly promotes selfexpression, individual thinking, personal choice, fostering independence and individual achievement, etc. This can answer why language learners had different styles in Reid's study and same styles in Wasanasomsithi's (2003) research. In terms of culture, this reason can be confirmed by Reid (1998) as he believes that people from different culture of language learning and strategies may value different learning characteristics. Moreover, Marshall (1991, as cited in Wasanasomsithi, 2003) shows that teaching style may affect the learners' learning style. Therefore, this might affect the different learning styles' of learners.

Furthermore according to Reid (1998), learning styles are internally based characteristics and some theorists even believe that learning styles are rooted in fixed genetic traits. (as cited in Penger et al., 2008) Therefore, from the researcher's point of view, every individual has his styles of learning. This means that males or females, old or young learners or learners from 
Thailand or any other countries have their unique ways of learning that are rooted in fixed genetic traits or internally based characteristics that none of us can observe or investigate why they prefer this style instead of others.

For the language learning strategies, this current study shows that males and females had similar learning strategies. They both sometimes used the strategies. This disagrees with Kamarul et al. (2009) as they state that there are gender differences.

One of the reasons why there is no difference in learning strategies in both males and females in this study may be because of the culture and the educational system. For example, according to Wafa (2003), the study reported on the current English language learning strategies used by Arabic-speaking English-majors enrolled at An-Najah National University in Palestine. In general, the results showed that gender and proficiency had no significant differences on the use of strategies, which was similar to the result in this study. They believe that the use of some individual strategies could be attributed to culture and educational system in Palestine where students had very limited opportunities to use functional practice strategies especially in large classes. This is quite similar to the study's population that learners were in large classes. Also, according to Harley (1986) Singleton (1989) and Moyer (2004), the individual learner's age has been identified as a relevant factor that leads to different learning strategies as well as gender.

However, there are also many theorists who have different ideas from Harley (1986), Singleton (1989) and Moyer (2004). According to Graham (1997) who based her work on O'Malley \& Chamot (1990) and developed it further, Graham (1997) sees the learning strategies as inner processes which are difficult to observe. According to Ehrman and Oxford's (1990) study, they failed to discover any evidence of differing language learning strategy use between the two genders.

Furthermore, a study of Yang (1998) involves questionnaire and group interviews in Taiwan. It made some interesting discoveries about her students' language learning strategy use that although her students were aware of various language learning strategies, few of them actually reported using them (as cited in Griffith, 2004).

Therefore, in order to truly understand each learning styles and strategies, we have to consider a variety of variables and it is indeed needed for a further investigation.

\section{CONCLUSION}

For this part, the researcher would like to suggest some comments to readers toward the results of the study. The researcher would like to suggest that teachers should not focus on some activities that are appropriate to only one learning style but they should integrate them all in the class, so that learners with different leaning styles and strategy preferences can learn best. For example, for the benefits of learners, if teacher only uses pictures or graphs, only students with the visual style preference can learn best. This ignores the learners of the other styles. Moreover, before the class, teachers should do a survey in order to know the learners' preferences for the benefits of learners. For example, the teacher can use PLSPQ to find out the learners' preferences. Once teachers know the results, teachers can arrange the teaching style that matches the learners' needs.

For learning strategies, the results of the study show no differences. Both males and females sometimes use learning strategies. This may be because of the age factor. The population in this study is 20 or 21 years of age. Therefore, according to Harley (1986), Singleton (1989) and Moyer (2004), age is considered to be one of the factors that affect 
language learning strategies. As a result, this study cannot be generalized to different age group population.

These previous studies show that Asian students are likely to sometimes use the strategies with no difference between males and females. As a result, as the population of this study is Asian or Thai students, the results of the previous studies also matches with this study. There are also similar research findings on this matter.

Goh and Foong (1991) study gender and the language learning strategies of Chinese students who learn English as a second language at Nanyang Technological University in Singapore. The result shows that all students sometimes use the strategies. The population is around 19 years of age and study English for at least six years. They use Oxford's SILL version 7.0 as an instrument. Moreover, Lee (2003) and Su (2005), study language learning strategies of Asian students who learn English as a second language and use SILL of Oxford version 7.0 as an instrument. Their result for overall language learning strategies is that all students sometimes use the strategies with no differences between males and females.

However, Bremner (1999) studies the language learning strategies of 149 Hong Kong students with 36 males and 113 females students using SILL of Oxford version 7.0. The results of the study are quite different from the others. It shows that students have some strategies that they use more than the others. Compensation and metacognitive strategies are used the most and memory strategy is of their least preference.

From the researcher's perspective, I would like to suggest that Asian students tend to have learning strategies used in the same direction, which sometimes use the strategies. On the other hand, there are a few studies like Bremner (1999) that show the result in an opposite direction. As a result, this topic still needs further investigation.

\section{REFERENCES}

Bremner, S. (1999). Language Learning Strategies and Language Proficiency: Investigating the Relationship in Hong Kong. Canadian Modern Language Review. 5(4), pp. 490-514. Retrieved from

http://utpjournals.metapress.com/content/ d27w088833436k7x/

Ebel, R. (1999). Encyclopaedia of educational research. Toronto: Engros.

Ehrman, M. \& Oxford, R. (1990). Adult language learning styles and strategies in an intensive training setting, The modern language journal, 74(3), 311-327.

Ellis, R. (1994). The study of second language acquisition. Oxford: Oxford University Press.

Graham, S. (1997). Effective Language Learning. Clevedon: Multilingual Matters.

Griffiths C. (2004, February 4). Language Learning Strategies: Theory and Research. Occasional Paper, 1. Retrieved from

http://www.crie.org.nz/research_paper/c griffiths_op1.pdf.

Goh, C. C. M. \& Foong, K. P. (1997). Chinese ESL Students' Learning Strategies: A Look at Frequency, Proficiency, and Gender. Hong Kong Journal of Applied Linguistics, 2(1) June, pp. 39-53. Retrieved from sunzi.lib.hku.hk/hkjo/view/5/500018.pdf

Harley, B. (1986). Age in second language acquisition. Clevedon: Multilingual Matters.

Kamarul, S. M. T., Mohamed A. E., Nik M. R. N., Yusoff, Zamri M. (2009). A Closer Look at Gender and Arabic Language Learning Strategies Use, European Journal of Social Sciences, 9(3). Retrieved from ttp://www.eurojournals.com/ejss_9_3_04. pdf 
Kim, S. J. (2004). Coping with Cultural Obstacles to Speaking English in the Korean Secondary School Context. Asian EFL Journal, 6, 1-11. Retrieved from http://www.asian-efljournal.com/Sept_04_ksj.pdf

Kim, U., Triandis, H., C., Choi, S-C., \& Yoon, G. (1984). Individualism and collectivism: Theory, method, and application. Thousand Oaks CA: Sage.

Kraft, C. \& Nichel, B. (1995). Review Essay: Perspectives on Languages and Communications, Journal of Women in Culture and Society, 3, pp. 638-651.

Lee K. O. (2003). The relationship of school year, sex and proficiency on the use of learning strategies in learn English of Korean junior high school students. Asian EFL Journal. September. Retrieved from http://www.asian-efljournal.com/sept_03_ok.php

Marshall, C. (1991). Teachers' learning styles: how they affect student learning. The Clearing House, 64, pp. 225-226.

Maubacha, A.M. and Morgan C. (2001).The relationship between gender and learning styles amongst A level modern languages students, Language Learning Journal, Summer, 23,pp. 41-47. Retrieved from http://www.ittmfl.org.uk/modules/teachin g/1f/paper1f3.PDF

Moyer, A. (2004). Age, Accent and Experience in Second Language Acquisition. Clevedon: Multilingual Matters.

Mulalic, A., Parilah M. S., Fauziah A. (2009). Perceptual Learning Styles of ESL Students. European Journal of Social Sciences ,7(3). Retrieved from http://www.eurojournals.com/ejss_7_3_1 $0 . p d f$

O'Malley, J.M. \& Chamot, A.U. (1990). Learning Strategies in Second Language Acquisition. Cambridge: Cambridge University Press.
Oxford, R.L. \& Nyikos, M. (1989). Variables affecting choice of language learning strategies by university students. The Modern Language Journal, 73(3), pp. 291-300.

Oxford, R. L. (1990). Language learning strategies: what every teacher should know. Boston Mass: Heinle a Heinle Publishers.

Penger et al. (2004). Comparison, validation and implications of learning style theories in higher education In

Purpura, J. E. (1999). Learner strategy use and performance on language tests: A structural equation modeling approach. Cambridge: Press Syndicate of the University of Cambridge.

Reid, J. M. (1984). Perceptual learning styles preference questionnaire available, from J. Reid, Department of English, University of Wyoming, Laramie, WY 82070 (1987) The perceptual learning style preferences of ESL students. TESOL Quarterly, 21, pp. 87-111.

Reid, J. M. (1987). The Learning Style Preferences of ESL Students TESOL Quarterly, 2l(1). Retrieved from http://hufs.davidboesch.com/GSE_YLDo wnloads/Reid.Joy.LearningStylePreferene sESLLearners.pdf

Reid, J. M. (1998). Understanding learning styles in the second language classroom. United States of America: Prentice Hall Regents.

Singleton, D. (1989). Language Acquisition: The age factor. Clevedon: Multilingual Matters.

Su, M. (2005). A Study of EFL Technological and Vocational college Students' Language Learning Strategies and their Self-Perceived English proficiency. Journal of Foreign Language Teaching. 2(1)Retrieved from http://eflt.nus.edu.sg/v2n12005/su.htm

Taguchi, T. (2002). Learner factors affecting the use of learning strategies in cross- 
cultural contexts. Prospect, 17(2), pp. 1834

Tannen, D. (1992). You just don't understand. New York: William Morrow.

Tatarinceva, A. (2009). Influence of the gender factor on a student's learning style and achievements in language learning. Transport and Telecommunication Institute. Retrieved from www.tsi.lv/Research/Conference/MIP_20 09/12.pdf

Wafa A.S. (2003) Language learning strategy use in Palestine, TESL-EJ, 7(2). Retrieved from http://www.teslej.org/wordpress/issues/volume7/ej26/ej2 6a3/

Wasanasomsithi, P. (2003). A study of learning style of EFL learners. Retrieved 25 December, 2012, from http://www.culi.chula.ac.th/

Watanasin, P. (2004). A study of learning styles of students enrolled in one business English class at the university level. (Master of Arts thesis, degree in Business English for international communication at Srinakharinwirot university)

Wehrwein, E. A., Heidi L. L. and Stephen E. D. C. (2007), Gender differences in learning style preferences among undergraduate physiology students, Advan. Physiol. Edu. 31, 153-157. Retrieved from http://advan.physiology.org/cgi/content/fu $11 / 31 / 2 / 153$

Yang, N.D. (1998). An interviewing study of college students' English learning strategy use, Studies in English language and literature, 4, 1-11. 